\title{
Syntheses, crystal structures and properties of complexes with two anthracene-based bulky backbone ligands
}

\author{
Jun-Jie Wang • Dao-Jun Zhang • Ren-Chun Zhang • \\ Xiao-Li Lu $\cdot$ Er-Ni Wang $\cdot$ Feng Jin • \\ Yun-Feng Shi
}

Received: 28 July 2014/ Accepted: 13 October 2014/Published online: 31 October 2014

(C) The Author(s) 2014. This article is published with open access at Springerlink.com

\begin{abstract}
Three metal-organic complexes with two anthracene-based bulky backbone ligands 9,10-dioxo-9, 10-dihydroanthracene-1,5-dicarboxylic acid $\left(\mathrm{H}_{2} \mathbf{L}^{1}\right)$ and 2-phenylquinoline-4-carboxylic acid $\left(\mathrm{HL}^{2}\right)$, namely $\left\{\left[\mathrm{Mn}\left(\mathbf{L}^{1}\right)_{0.5}\left(\mathbf{L}^{1}\right)_{0.5}(\text { phen })\left(\mathrm{H}_{2} \mathrm{O}\right)_{2}\right]\left(\mathrm{H}_{2} \mathrm{O}\right)_{1.5}\right\}_{\infty}(\mathbf{1}),\left[\mathrm{Mn}_{2}\left(\mathbf{L}^{2}\right)_{4^{-}}\right.$ (phen $\left.)_{2}\left(\mathrm{H}_{2} \mathrm{O}\right)_{2}\right]\left(\mathrm{H}_{2} \mathrm{O}\right)_{2} \quad(\mathbf{2})$ and $\left[\mathrm{Cd}_{3}\left(\mathbf{L}^{2}\right)_{2}(\mathrm{pp})_{2} \mathrm{Cl}_{4}\right]_{\infty} \quad$ (3) (phen $=1,10$-phenanthroline, $\mathrm{pp}=3$-(2-pyridyl)pyrazole), have been synthesized and characterized. X-ray singlecrystal diffraction indicates that $\mathrm{H}_{2} \mathbf{L}^{1}$ adopts a bis-monodentate bridging mode in complex $\mathbf{1}$, whereas $\mathrm{HL}^{2}$ adopts monodentate and bidentate bridging modes in $\mathbf{2}$ and a tridentate bridging mode in $\mathbf{3}$. The chelating ligands phen and pp give rise to a $1 \mathrm{D}$ zigzag chain in complexes $\mathbf{1}$ and $\mathbf{3}$, and a binuclear structure in $\mathbf{2}$, by preventing the formation of higher-dimensional structures. Notably, the anions play an important role in the structure of complex 3 . In addition, the magnetic and luminescent properties of these complexes were investigated.
\end{abstract}

\section{Introduction}

The design of metal-organic crystalline materials has attracted considerable attention due to their interesting architectures and applications in optics, magnetism, gas storage, ion exchange and catalysis $[1,2]$. The structural

J.-J. Wang $(\bowtie) \cdot$ D.-J. Zhang $\cdot$ R.-C. Zhang $\cdot$ X.-L. Lu •

E.-N. Wang · F. Jin · Y.-F. Shi $(\bowtie)$

College of Chemistry and Chemical Engineering, Anyang

Normol University, Anyang 455000, Henan, People's Republic

of China

e-mail: jjwang@aynu.edu.cn

Y.-F. Shi

e-mail: shiyunfeng2009@gmail.com and functional properties of such target materials vary significantly with the metal and ligand choice $[1,2]$. In this respect, a variety of organic building blocks containing pyridyl and/or carboxylate functional groups have been intensely investigated [1-4], and the rational design of new types of organic ligands for constructing unusual coordination polymers is obviously not a trivial problem at this stage. Ligands with bulky backbones are important in the field of coordination chemistry, because of their steric hindrance effects $[5,6]$. Very recently, increasing numbers of investigations have been focused on the self-assembly of such bulky backbone multidentate ligands with metals. This can lead to the formation of either discrete polynuclear complexes or low-dimensional coordination polymers, which display such useful properties as luminescence, and sensor ability. Additionally, auxiliary ligands [7], counteranions [8], as well as synthesis conditions [9], including the $\mathrm{pH}$ value of the reaction solution [10], temperature [11], molar ratio between reactants [12] and solvent system [13], can all play an important role in the formation of such complexes.

In our previous work, several anthracene-based bulky backbone ligands, namely acridine-9-carboxylic acid [14], anthracene-9-carboxylic acid [15], anthracene-9,10-dicarboxylic acid $[15,16]$ and anthracene-1,5-dicarboxylic acid [16], were used to construct a range of metal coordination compounds, showing interesting luminescent, magnetic and gas adsorption properties. By contrast, anthracenebased bulky backbone ligands, such as phenylquinoline$[17,18]$ and anthraquinone-based carboxylic acids [19, 20], have not yet been widely studied. Therefore, we have selected two anthracene-based bulky backbone ligands, 9,10-dioxo-9,10-dihydroanthracene-1,5-dicarboxylic acid $\left(\mathrm{H}_{2} \mathbf{L}^{1}\right)$ and 2-phenylquinoline-4-carboxylic acid $\left(\mathrm{HL}^{2}\right)$ (Fig. 1), together with 1,10-phenanthroline (phen) or 3-(2- 
<smiles>O=C(O)c1cccc2c1C(=O)c1cccc(C(=O)O)c1C2=O</smiles>

$\mathbf{H}_{2} \mathbf{L}^{1}$

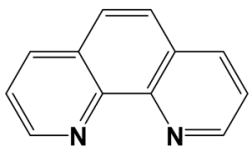

phen<smiles>O=C(O)c1cc(-c2ccccc2)nc2ccccc12</smiles>

$\mathrm{HL}^{2}$

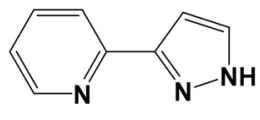

pp

Fig. 1 The ligands used in this work

pyridyl)pyrazole (pp) as auxiliary ligands, to construct three $\mathrm{Mn}^{\mathrm{II}}$ and $\mathrm{Cd}^{\mathrm{II}}$ coordination compounds, namely $\left\{\left[\mathrm{Mn}\left(\mathbf{L}^{1}\right)_{0.5}\left(\mathbf{L}^{1}\right)_{0.5}(\text { phen })\left(\mathrm{H}_{2} \mathrm{O}\right)_{2}\right]\left(\mathrm{H}_{2} \mathrm{O}\right)_{1.5}\right\}_{\infty} \quad(\mathbf{1})$, $\left[\mathrm{Mn}_{2}\left(\mathbf{L}^{2}\right)_{4}(\text { phen })_{2}\left(\mathrm{H}_{2} \mathrm{O}\right)_{2}\right]\left(\mathrm{H}_{2} \mathrm{O}\right)_{2}(\mathbf{2})$ and $\left[\mathrm{Cd}_{3}\left(\mathbf{L}^{2}\right)_{2}(\mathrm{pp})_{2^{-}}\right.$ $\left.\mathrm{Cl}_{4}\right]_{\infty}$ (3) (phen = 1,10-phenanthroline, pp = 3-(2-pyridyl)pyrazole). To facilitate the generation and crystallization of these complexes, the hydrothermal synthetic method has been employed [21]. The magnetic and luminescent properties of these complexes have been investigated.

\section{Experimental}

Materials and methods

9,10-Dioxo-9,10-dihydroanthracene-1,5-dicarboxylic acid $\left(\mathrm{H}_{2} \mathbf{L}^{1}\right.$, Scheme 1) was synthesized according to the literature procedure [22]. All other reagents and solvents for synthesis were commercially available and used as received or purified by standard methods prior to use. Elemental analyses $(\mathrm{C}, \mathrm{H}, \mathrm{N})$ were obtained on a PerkinElmer 240C analyzer. IR spectra were recorded on a Varian 800 (Scimitar Series) FT-IR spectrometer with $\mathrm{KBr}$ pellets. Emission spectra in the solid state were taken on a Cary Eclips fluorescence spectrophotometer at room temperature. Magnetic measurements were carried out with a quantum design MPMS-XL-7 magnetometer.

\section{Preparation of complex 1}

A mixture of $\mathrm{H}_{2} \mathbf{L}^{1}$ (148 $\mathrm{mg}, 0.5 \mathrm{mmol}$ ), phen (99 mg, $1.2 \mathrm{mmol}$ ) and $\mathrm{MnCl}_{2} \cdot 2 \mathrm{H}_{2} \mathrm{O}(324 \mathrm{mg}, 2 \mathrm{mmol})$ was dissolved in water $(15 \mathrm{~mL})$. The resultant solution was sealed in a Teflon-lined stainless autoclave and heated to $160{ }^{\circ} \mathrm{C}$. After keeping in these conditions for 3 days, the reaction vessel was allowed to cool. Yellow single crystals suitable for X-ray analysis were obtained after cooling to room

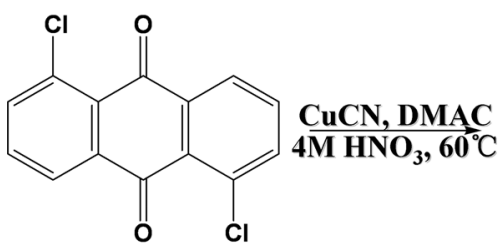<smiles>N#Cc1cccc2c1C(=O)c1cccc(C#N)c1C2=O</smiles><smiles>C[14C](=O)OC1c2cccc(C(=O)O)c2C(=O)c2cccc(C(=O)O)c21</smiles>

Scheme 1 Synthetic route for $\mathrm{H}_{2} \mathbf{L}^{1}$

temperature. Yield: $\sim 40 \%$ based on $\mathrm{H}_{2} \mathbf{L}^{1}$. Calcd. (\%) for $\mathrm{C}_{56} \mathrm{H}_{42} \mathrm{~N}_{4} \mathrm{O}_{19} \mathrm{Mn}_{2}: \mathrm{C}, 56.8 ; \mathrm{H}, 3.6, \mathrm{~N}, 4.7$; found (\%): C, 56.3; H, 3.9, N, 4.3. IR ( $\mathrm{KBr}$ pellet, $\left.\mathrm{cm}^{-1}\right)$ : 3,374 s(br), $3,075 \mathrm{w}, 1,689 \mathrm{~s}, 1,567 \mathrm{~s}, 1,517 \mathrm{~s}, 1,466 \mathrm{~m}, 1,438 \mathrm{w}, 1,407$ $\mathrm{s}, 1,326 \mathrm{~s}, 1,275 \mathrm{~s}, 1,232 \mathrm{w}, 1,167 \mathrm{w}, 1,137 \mathrm{w}, 1,094 \mathrm{w}$, 1,008 w, 865 w, 844 w, 827 m, 807 w, 783 w, 770 m, 727 $\mathrm{m}, 711 \mathrm{~s}, 686 \mathrm{~m}, 614 \mathrm{w}, 421 \mathrm{w}$.

\section{Preparation of complex $\mathbf{2}$}

An ethanol solution $(10 \mathrm{~mL})$ of $\mathrm{HL}^{2}(13 \mathrm{mg}, 0.05 \mathrm{mmol})$, phen ( $9 \mathrm{mg}, 0.05 \mathrm{mmol}$ ) and excess 2,6-dimethylpyridine (ca. $0.05 \mathrm{~mL}$ for adjusting the $\mathrm{pH}$ value) was carefully layered on top of an aqueous solution $(15 \mathrm{~mL})$ of $\mathrm{Mn}\left(\mathrm{ClO}_{4}\right)_{2} \cdot 6 \mathrm{H}_{2} \mathrm{O}(36 \mathrm{mg}, 0.1 \mathrm{mmol})$ in a test tube. Yellow single crystals suitable for X-ray analysis appeared at the boundary between the layers after ca. 1 month at room temperature. Yield: $\sim 30 \%$ based on $\mathrm{HL}^{2}$. Calcd. (\%) for $\mathrm{C}_{88} \mathrm{H}_{64} \mathrm{~N}_{8} \mathrm{O}_{12} \mathrm{Mn}_{2}$ : C, 68.8, H, 4.2, N, 7.3; found (\%): C, 69.1, H, 4.5, N, 7.4. IR ( $\mathrm{KBr}$ pellet, $\mathrm{cm}^{-1}$ ): 3,464 s(br), $1,692 \mathrm{~s}, 1,573 \mathrm{~s}, 1,548 \mathrm{~m}, 1,517 \mathrm{~s}, 1,458 \mathrm{~m}, 1,427 \mathrm{~s}, 1,380$ $\mathrm{s}, 1,373 \mathrm{~s}, 1,319 \mathrm{~m}, 1,234 \mathrm{~m}, 1,140 \mathrm{~m}, 1,025 \mathrm{~m}, 914 \mathrm{w}, 865$ w, $813 \mathrm{~m}, 769$ s, $726 \mathrm{~m}, 651 \mathrm{~m}, 567 \mathrm{w}, 514$ w, 411 w.

Preparation of complex $\mathbf{3}$

The same procedure as that for $\mathbf{2}$ was used for this complex except that $\mathrm{Mn}\left(\mathrm{ClO}_{4}\right)_{2} \cdot 6 \mathrm{H}_{2} \mathrm{O}$ and phen were replaced by $\mathrm{CdCl}_{2} \cdot 2.5 \mathrm{H}_{2} \mathrm{O}$ and $\mathrm{pp}$, respectively. Light yellow single crystals suitable for X-ray analysis were obtained after cooling to room temperature. Yield: $\sim 20 \%$ based on $\mathrm{HL}^{2}$. Calcd. (\%) for $\mathrm{C}_{48} \mathrm{H}_{34} \mathrm{~N}_{8} \mathrm{O}_{4} \mathrm{Cl}_{4} \mathrm{Cd}_{3}$ : C, 45.4, H, 2.7, N, 8.8; found (\%): C, 45.6, H, 2.5, N, 8.6. IR ( $\mathrm{KBr}$ pellet, $\mathrm{cm}^{-1}$ ): $3,473 \mathrm{~s}(\mathrm{br}), 3,126 \mathrm{~m}, 1,641 \mathrm{w}, 1,601 \mathrm{~m}, 1,570 \mathrm{~s}, 1,544 \mathrm{~m}$, 
Table 1 Crystallographic data and structure refinement summary for compounds 1-3

\begin{tabular}{|c|c|c|c|}
\hline & 1 & 2 & 3 \\
\hline Chemical formula & $\mathrm{C}_{56} \mathrm{H}_{42} \mathrm{Mn}_{2} \mathrm{~N}_{4} \mathrm{O}_{19}$ & $\mathrm{C}_{88} \mathrm{H}_{64} \mathrm{Mn}_{2} \mathrm{~N}_{8} \mathrm{O}_{12}$ & $\mathrm{C}_{48} \mathrm{H}_{34} \mathrm{Cd}_{3} \mathrm{Cl}_{4} \mathrm{~N}_{8} \mathrm{O}_{4}$ \\
\hline Formula weight & $1,184.82$ & $1,535.35$ & $1,265.83$ \\
\hline Crystal system & Triclinic & Monoclinic & Monoclinic \\
\hline Space group & $P-1$ & $P 2(1) / c$ & $C 2 / c$ \\
\hline$a(\AA)$ & $10.436(2)$ & $14.950(3)$ & $33.165(7)$ \\
\hline$b(\AA)$ & $10.948(2)$ & $13.898(3)$ & $8.1955(16)$ \\
\hline$c(\AA)$ & $14.223(3)$ & $17.752(4)$ & $17.164(3)$ \\
\hline$\alpha\left(^{\circ}\right)$ & $79.30(3)$ & 90 & 90 \\
\hline$\beta\left(^{\circ}\right)$ & $69.38(3)$ & $96.85(3)$ & $106.74(3)$ \\
\hline$\gamma\left({ }^{\circ}\right)$ & $61.76(3)$ & 90 & 90 \\
\hline$V\left(\AA^{3}\right)$ & $1,339.5(5)$ & $3,662.1(13)$ & $4,467.4(15)$ \\
\hline$Z$ & 1 & 2 & 4 \\
\hline$D\left(\mathrm{~g} \mathrm{~cm}^{-3}\right)$ & 1.469 & 1.392 & 1.882 \\
\hline$\mu\left(\mathrm{mm}^{-1}\right)$ & 0.553 & 0.417 & 1.711 \\
\hline$T(\mathrm{~K})$ & $293(2)$ & 293(2) & $293(2)$ \\
\hline GOF & 1.054 & 1.100 & 1.165 \\
\hline$R^{\mathrm{a}} / w R^{\mathrm{b}}$ & $0.0948 / 0.2803$ & $0.0768 / 0.1498$ & $0.0291 / 0.0504$ \\
\hline
\end{tabular}

$1,463 \mathrm{~s}, 1,432 \mathrm{~s}, 1,365 \mathrm{~m}, 1,313 \mathrm{~m}, 1,237 \mathrm{w}, 1,153 \mathrm{~m}$, $1,095 \mathrm{~m}, 1,068 \mathrm{w}, 1,023 \mathrm{w}, 970 \mathrm{w}, 879 \mathrm{w}, 848 \mathrm{w}, 808 \mathrm{w}$, 783 m, 764 s, 694 m, 637 m, 590 m, 515 w, 411 w.

X-ray powder diffraction studies

The X-ray powder diffraction patterns (XRPD) of complexes 1-3 were recorded on a Rigaku D/Max-2,500 diffractometer, operated at $40 \mathrm{kV}$ and $100 \mathrm{~mA}$, using a $\mathrm{Cu}-$ target tube and graphite monochromator. The intensity data were recorded by continuous scan in $2 \theta / \theta$ mode from $3^{\circ}$ to $40^{\circ}$ with a step size of $0.02^{\circ}$ and a scan speed of $8^{\circ} \mathrm{min}^{-1}$.

X-ray crystallographic studies

X-ray single-crystal diffraction measurements for complexes 1-3 were carried out on a Bruker Smart 1000 CCD diffractometer equipped with a graphite crystal monochromator situated in the incident beam for data collection at 293(2) K. The determinations of unit cell parameters and data collections were performed with $\mathrm{Mo}-\mathrm{K}_{\alpha}$ radiation ( $\lambda=0.71,073 \AA$ ), and unit cell dimensions were obtained with least-square refinements. The program SAINT [23] was used for integration of the diffraction profiles. Semiempirical absorption corrections were applied using the SADABS program [24]. All the structures were solved by direct methods using the SHELXS program of the SHELXTL package and refined with SHELXL [25]. Metal atoms in each complex were located from the $E$-maps, and other non-hydrogen atoms were located in successive difference Fourier syntheses and refined with anisotropic thermal parameters on $F^{2}$. The hydrogen atoms were added theoretically, riding on the atoms concerned and refined with fixed thermal factors. Crystallographic data and experimental details for the structural analyses are summarized in Table 1. Selected bond distances and angles are listed in Table 2. CCDC nos 942732, 942731 and 942730 contain the supplementary crystallographic data for complexes $\mathbf{1}-$ $\mathbf{3}$, respectively. This material can be obtained free of charge via http://www.ccdc.cam.ac.uk/conts/retrieving. html, or from the Cambridge Crystallographic Data Centre, 12 Union Road, Cambridge CB2 1EZ, UK; fax: (+44) 1223-336-033; or E-mail: deposit@ccdc.cam.ac.uk.

\section{Results and discussion}

Synthesis and general characterization

In general, reducing the reaction speed may result in the slow growth of well-shaped larger single crystals suitable for X-ray diffraction [26]. With this in mind, the synthesis and isolation of complexes $\mathbf{2}$ and $\mathbf{3}$ were carried out through self-assembly reactions of $\mathrm{Mn}\left(\mathrm{ClO}_{4}\right)_{2} \cdot 6 \mathrm{H}_{2} \mathrm{O}$ or $\mathrm{CdCl}_{2} \cdot 2.5 \mathrm{H}_{2} \mathrm{O}$ with $\mathrm{HL}^{2}$, together with phen or pp as chelating co-ligands, by using the slow diffusion method 
Table 2 Selected bond lengths $(\AA)$ and angles $\left({ }^{\circ}\right)$ for compounds 1-3

1

\begin{tabular}{|c|c|c|c|}
\hline $\mathrm{Mn}(1)-\mathrm{O}(4)$ & $2.150(5)$ & $\mathrm{Mn}(1)-\mathrm{O}(1)$ & $2.158(5)$ \\
\hline $\mathrm{Mn}(1)-\mathrm{O}(2 \mathrm{~W})$ & $2.176(8)$ & $\mathrm{Mn}(1)-\mathrm{O}(1 \mathrm{~W})$ & $2.179(7)$ \\
\hline $\mathrm{Mn}(1)-\mathrm{N}(2)$ & $2.284(5)$ & $\mathrm{Mn}(1)-\mathrm{N}(1)$ & $2.306(5)$ \\
\hline $\mathrm{O}(4)-\mathrm{Mn}(1)-\mathrm{O}(1)$ & $166.46(15)$ & $\mathrm{O}(4)-\mathrm{Mn}(1)-\mathrm{O}(2 \mathrm{~W})$ & $83.6(2)$ \\
\hline $\mathrm{O}(1)-\mathrm{Mn}(1)-\mathrm{O}(2 \mathrm{~W})$ & $89.1(2)$ & $\mathrm{O}(4)-\mathrm{Mn}(1)-\mathrm{O}(1 \mathrm{~W})$ & $88.0(2)$ \\
\hline $\mathrm{O}(1)-\mathrm{Mn}(1)-\mathrm{O}(1 \mathrm{~W})$ & $82.2(2)$ & $\mathrm{O}(2 \mathrm{~W})-\mathrm{Mn}(1)-\mathrm{O}(1 \mathrm{~W})$ & $100.8(3)$ \\
\hline $\mathrm{O}(4)-\mathrm{Mn}(1)-\mathrm{N}(2)$ & $97.73(18)$ & $\mathrm{O}(1)-\mathrm{Mn}(1)-\mathrm{N}(2)$ & $92.28(18)$ \\
\hline $\mathrm{O}(2 \mathrm{~W})-\mathrm{Mn}(1)-\mathrm{N}(2)$ & $165.1(3)$ & $\mathrm{O}(1 \mathrm{~W})-\mathrm{Mn}(1)-\mathrm{N}(2)$ & $94.1(2)$ \\
\hline $\mathrm{O}(4)-\mathrm{Mn}(1)-\mathrm{N}(1)$ & $96.14(18)$ & $\mathrm{O}(1)-\mathrm{Mn}(1)-\mathrm{N}(1)$ & $95.58(18)$ \\
\hline $\mathrm{O}(2 \mathrm{~W})-\mathrm{Mn}(1)-\mathrm{N}(1)$ & $92.7(2)$ & $\mathrm{O}(1 \mathrm{~W})-\mathrm{Mn}(1)-\mathrm{N}(1)$ & $166.3(2)$ \\
\hline $\mathrm{N}(2)-\mathrm{Mn}(1)-\mathrm{N}(1)$ & $72.37(19)$ & & \\
\hline \multicolumn{4}{|l|}{2} \\
\hline $\mathrm{Mn}(1)-\mathrm{O}(1) \# 1$ & $2.120(3)$ & $\mathrm{Mn}(1)-\mathrm{O}(2)$ & $2.165(3)$ \\
\hline $\mathrm{Mn}(1)-\mathrm{O}(3)$ & $2.177(3)$ & $\mathrm{Mn}(1)-\mathrm{O}(1 \mathrm{~W})$ & $2.244(3)$ \\
\hline $\operatorname{Mn}(1)-N(3)$ & $2.275(3)$ & $\mathrm{Mn}(1)-\mathrm{N}(4)$ & $2.295(3)$ \\
\hline $\mathrm{O}(1) \# 1-\mathrm{Mn}(1)-\mathrm{O}(2)$ & $93.08(10)$ & $\mathrm{O}(1) \# 1-\mathrm{Mn}(1)-\mathrm{O}(3)$ & $93.66(12)$ \\
\hline $\mathrm{O}(2)-\mathrm{Mn}(1)-\mathrm{O}(3)$ & $93.52(11)$ & $\mathrm{O}(1) \# 1-\mathrm{Mn}(1)-\mathrm{O}(1 \mathrm{~W})$ & $83.29(11)$ \\
\hline $\mathrm{O}(2)-\mathrm{Mn}(1)-\mathrm{O}(1 \mathrm{~W})$ & $173.21(11)$ & $\mathrm{O}(3)-\mathrm{Mn}(1)-\mathrm{O}(1 \mathrm{~W})$ & $92.45(12)$ \\
\hline $\mathrm{O}(1) \# 1-\mathrm{Mn}(1)-\mathrm{N}(3)$ & $101.26(12)$ & $\mathrm{O}(2)-\mathrm{Mn}(1)-\mathrm{N}(3)$ & $89.83(11)$ \\
\hline $\mathrm{O}(3)-\mathrm{Mn}(1)-\mathrm{N}(3)$ & $164.52(11)$ & $\mathrm{O}(1 \mathrm{~W})-\mathrm{Mn}(1)-\mathrm{N}(3)$ & $85.27(12)$ \\
\hline $\mathrm{O}(1) \# 1-\mathrm{Mn}(1)-\mathrm{N}(4)$ & $173.09(12)$ & $\mathrm{O}(2)-\mathrm{Mn}(1)-\mathrm{N}(4)$ & $91.31(10)$ \\
\hline $\mathrm{O}(3)-\mathrm{Mn}(1)-\mathrm{N}(4)$ & $91.40(11)$ & $\mathrm{O}(1 \mathrm{~W})-\mathrm{Mn}(1)-\mathrm{N}(4)$ & $91.79(11)$ \\
\hline $\mathrm{N}(3)-\mathrm{Mn}(1)-\mathrm{N}(4)$ & $73.40(12)$ & & \\
\hline \multicolumn{4}{|l|}{3} \\
\hline $\mathrm{Cd}(1)-\mathrm{O}(1)$ & $2.2858(19)$ & $\mathrm{Cd}(1)-\mathrm{Cl}(2)$ & $2.6101(9)$ \\
\hline $\mathrm{Cd}(1)-\mathrm{Cl}(1)$ & $2.6484(10)$ & $\mathrm{Cd}(2)-\mathrm{O}(2) \# 1$ & $2.3161(19)$ \\
\hline $\mathrm{Cd}(2)-\mathrm{N}(2)$ & $2.317(3)$ & $\mathrm{Cd}(2)-\mathrm{N}(1)$ & $2.369(2)$ \\
\hline $\mathrm{Cd}(2)-\mathrm{O}(2) \# 2$ & $2.429(2)$ & $\mathrm{Cd}(2)-\mathrm{Cl}(1)$ & $2.5726(8)$ \\
\hline $\mathrm{Cd}(2)-\mathrm{Cl}(2)$ & $2.5946(9)$ & & \\
\hline $\mathrm{O}(1) \# 1-\mathrm{Cd}(1)-\mathrm{O}(1)$ & $176.32(12)$ & $\mathrm{O}(1)-\mathrm{Cd}(1)-\mathrm{Cl}(2)$ & $94.10(6)$ \\
\hline $\mathrm{O}(1)-\mathrm{Cd}(1)-\mathrm{Cl}(2) \# 1$ & $83.32(6)$ & $\mathrm{Cl}(2)-\mathrm{Cd}(1)-\mathrm{Cl}(2) \# 1$ & $91.52(4)$ \\
\hline $\mathrm{O}(1)-\mathrm{Cd}(1)-\mathrm{Cl}(1) \# 1$ & $93.49(6)$ & $\mathrm{Cl}(2)-\mathrm{Cd}(1)-\mathrm{Cl}(1) \# 1$ & $172.24(2)$ \\
\hline $\mathrm{O}(1)-\mathrm{Cd}(1)-\mathrm{Cl}(1)$ & $89.03(6)$ & $\mathrm{Cl}(2)-\mathrm{Cd}(1)-\mathrm{Cl}(1)$ & $87.77(3)$ \\
\hline $\mathrm{Cl}(1) \# 1-\mathrm{Cd}(1)-\mathrm{Cl}(1)$ & $93.98(4)$ & $\mathrm{O}(2) \# 1-\mathrm{Cd}(2)-\mathrm{N}(2)$ & $95.03(8)$ \\
\hline $\mathrm{O}(2) \# 1-\mathrm{Cd}(2)-\mathrm{N}(1)$ & $165.80(8)$ & $\mathrm{N}(2)-\mathrm{Cd}(2)-\mathrm{N}(1)$ & $70.77(9)$ \\
\hline $\mathrm{O}(2) \# 1-\mathrm{Cd}(2)-\mathrm{O}(2) \# 2$ & $77.19(7)$ & $\mathrm{N}(2)-\mathrm{Cd}(2)-\mathrm{O}(2) \# 2$ & $82.64(9)$ \\
\hline $\mathrm{N}(1)-\mathrm{Cd}(2)-\mathrm{O}(2) \# 2$ & $99.84(7)$ & $\mathrm{O}(2) \# 1-\mathrm{Cd}(2)-\mathrm{Cl}(1)$ & $99.08(6)$ \\
\hline $\mathrm{N}(2)-\mathrm{Cd}(2)-\mathrm{Cl}(1)$ & $162.93(7)$ & $\mathrm{N}(1)-\mathrm{Cd}(2)-\mathrm{Cl}(1)$ & $94.85(6)$ \\
\hline $\mathrm{O}(2) \# 2-\mathrm{Cd}(2)-\mathrm{Cl}(1)$ & $91.15(5)$ & $\mathrm{O}(2) \# 1-\mathrm{Cd}(2)-\mathrm{Cl}(2)$ & $92.77(6)$ \\
\hline $\mathrm{N}(2)-\mathrm{Cd}(2)-\mathrm{Cl}(2)$ & $99.16(8)$ & $\mathrm{N}(1)-\mathrm{Cd}(2)-\mathrm{Cl}(2)$ & $90.07(6)$ \\
\hline $\mathrm{O}(2) \# 2-\mathrm{Cd}(2)-\mathrm{Cl}(2)$ & $169.94(5)$ & $\mathrm{Cl}(1)-\mathrm{Cd}(2)-\mathrm{Cl}(2)$ & $89.73(3)$ \\
\hline
\end{tabular}

Symmetry transformation used to generate equivalent atoms: for $\mathbf{2}$ : \#1, $-x,-y$, $-z+2$; for 3: \#1, $-x, y,-z+1 / 2 ; \# 2, x,-y+1, z+1 / 2$

under mild conditions of ambient temperature and pressure. However, under the same conditions, the reaction of $\mathrm{Mn}^{\mathrm{II}}$ and $\mathrm{H}_{2} \mathbf{L}^{1}$ gave only some precipitate or microcrystalline products. Hydrothermal synthesis can minimize the problems associated with ligand solubility as well as enhancing the reactivity of reactants, so well-shaped single crystals of 1 were achieved by the high-temperature hydrothermal synthesis. Complexes 1-3 are all air stable. The compositions of these new materials were validated by elemental analyses and IR spectra. The phase purities of the bulk samples were checked by XRPD (see Fig. 7).

\section{Crystal structure of complex $\mathbf{1}$}

Similar to previous reports $[17,27,28], \mathrm{X}$-ray single-crystal diffraction analysis reveals that the asymmetric unit of $\mathbf{1}$ contains one $\mathrm{Mn}^{\mathrm{II}}$ atom, two half $\mathbf{L}^{1}$ ligands, one phen ligand, two coordinated water ligands and one and three half water molecules (Fig. 2). In other words, each $\mathrm{Mn}^{\mathrm{II}}$ center is six coordinated by two carboxylate $\mathrm{O}$ atoms from two $\mathbf{L}^{1}$ ligands, two $\mathrm{N}$ atoms from one phen ligand and two $\mathrm{O}$ atoms from two water ligands, forming a slightly distorted octahedral coordination geometry. Each $\mathbf{L}^{1}$ ligand coordinates to two $\mathrm{Mn}^{\mathrm{II}}$ atoms via its two carboxylate groups. Thus, the $\mathrm{Mn}^{\mathrm{II}}$ centers are linked by $\mathbf{L}^{1}$ ligands via a bis-monodentate bridging mode to result in 1D zigzag chains, which are prevented from forming higher-dimensional structures by the chelating phen ligands (Fig. 2a). The 1D zigzag chains are assembled to form a 3D supramolecular network by intermolecular $\mathrm{C}-\mathrm{H} \cdots$ O hydrogen bonds [ the $\mathrm{C}(3) \cdots \mathrm{O}(1 \mathrm{G})$ and $\mathrm{C}(11) \cdots \mathrm{O}(4 \mathrm{H})$ separations are 3.44(8) and 3.43(4) $\AA$ and the $\mathrm{C}(3)-\mathrm{H}(3) \cdots \mathrm{O}(1 \mathrm{G})$ and $\mathrm{C}(11)-\mathrm{H}(11) \cdots \mathrm{O}(4 \mathrm{H})$ angles are $155.00^{\circ}$ and $162.01^{\circ}$, symmetry code $\mathrm{G}=1-x$, $-y, 1-z ; \mathrm{H}=1-x,-y,-z]$ (Fig. 2b) $[29,30]$.

\section{Crystal structure of complex 2}

When we used $\mathrm{HL}^{2}$ instead of $\mathrm{H}_{2} \mathbf{L}^{1}$, a reported binuclear complex 2 was produced (Fig. 3) [31]. The $\mathrm{Mn}^{\mathrm{II}}$ centers are linked by $\mathbf{L}^{2}$ ligands via a bidentate bridging mode to form a binuclear structure, which is prevented from forming higherdimensional structures by the chelating phen and $\mathbf{L}^{2}$ ligands in a monodentate mode (Fig. 3a). The binuclear units are assembled to form a 3D supramolecular network by intermolecular $\mathrm{O}-\mathrm{H} \cdots \mathrm{O}$ hydrogen bonds [the $\mathrm{O}(2 \mathrm{~W}) \cdots \mathrm{O}(3 \mathrm{C})$ separation is $3.18(1) \AA$, and the $\mathrm{O}(2 \mathrm{~W})-\mathrm{H}(2 \mathrm{WB}) \cdots \mathrm{O}(3 \mathrm{C})$ angle is $169.67^{\circ}$, symmetry code $C=1-x,-y, 1-z$, $\mathrm{O}-\mathrm{H} \cdots \mathrm{N}$ hydrogen bonds [the $\mathrm{O}(1 \mathrm{~W}) \cdots \mathrm{N}(1 \mathrm{D})$ and $\mathrm{O}(2 \mathrm{~W}) \cdots \mathrm{N}(2 \mathrm{E})$ distances are 2.87(1) and 3.05(1) $\AA$, and the $\mathrm{O}(1 \mathrm{~W})-\mathrm{H}(1 \mathrm{WB}) \cdots \mathrm{N}(1 \mathrm{D})$ and $\mathrm{O}(2 \mathrm{~W})-\mathrm{H}(2 \mathrm{WA}) \cdots \mathrm{N}(2 \mathrm{E})$ angles are $175.11^{\circ}$ and $162.08^{\circ}$, symmetry code $D=-x$, $0.5+y, 1.5-z ; E=x, y,-1+z]$ and also $\mathrm{C}-\mathrm{H} \cdots \mathrm{O}$ hydrogen bonds [the $\mathrm{C}(40) \cdots \mathrm{O}(1 \mathrm{WF})$ separation is $3.48(1) \AA$, and the $\mathrm{C}(40)-\mathrm{H}(40) \cdots \mathrm{O}(1 \mathrm{WF})$ angle is $167.39^{\circ}$, symmetry code $F=x, 0.5-y,-0.5+z]$ (Fig. 3b) $[29,30]$.

Crystal structure of complex 3

Different from complex 2, the asymmetric unit of complex $\mathbf{3}$ is composed of one and a half $\mathrm{Cd}^{\mathrm{II}}$ atoms, one $\mathbf{L}^{2}$ ligand, one pp ligand and two $\mathrm{Cl}^{-}$ligands. The two $\mathrm{Cd}^{\mathrm{II}}$ centers 
Fig. 2 View of a the coordination environment of $\mathrm{Mn}^{\mathrm{II}}$ ions in the zigzag chain of $\mathbf{1}$, b the $3 \mathrm{D}$ supramolecular network showing the intramolecular $\mathrm{C}-\mathrm{H} \cdots \mathrm{O}$ hydrogen bond interactions (partial $\mathrm{H}$ atoms and dissociated aqua molecules omitted for clarity)
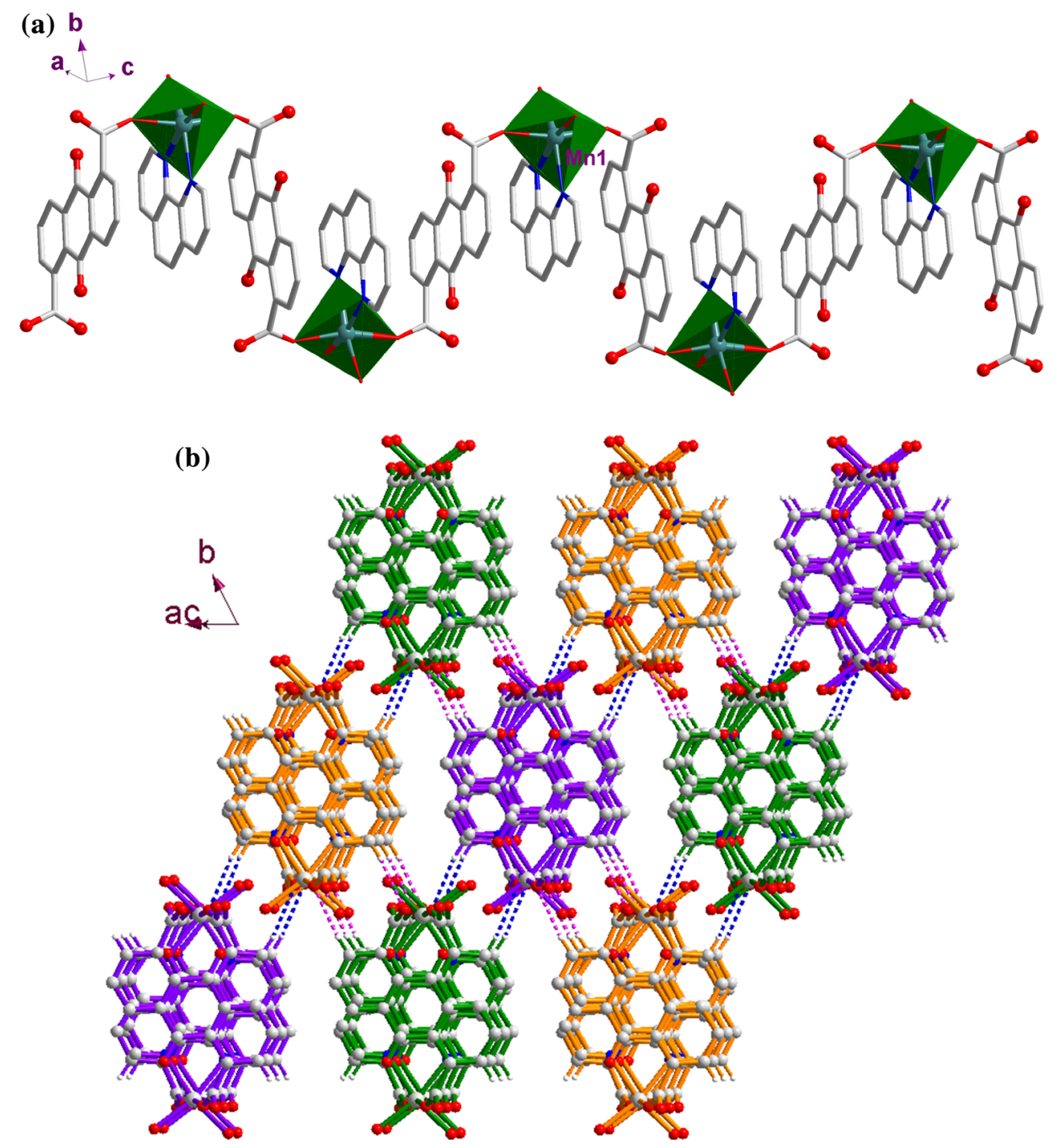

have different coordination spheres (see Fig. 4a; Table 2). $\mathrm{Cd}(1)$ is coordinated by two $\mathrm{O}$ atoms from two $\mathbf{L}^{2}$ ligands and four $\mathrm{Cl}^{-}$ligands, giving a distorted octahedral geometry. $\mathrm{Cd}(2)$ is six coordinated by two $\mathrm{O}$ atoms from two $\mathbf{L}^{2}$ ligands, two $\mathrm{N}$ atoms from one pp ligand and two $\mathrm{Cl}^{-}$ ligands to form a distorted octahedral geometry. Thus, pairs of $\mathrm{Cd}^{\mathrm{II}}$ centers are linked by $\mathbf{L}^{2}$ ligands via a tridentate bridging mode and bridging $\mathrm{Cl}^{-}$ligands to result in a 1D zigzag chain (Fig. 4b). These 1D chains are assembled into a 2D supramolecular network by intermolecular $\mathrm{C}-\mathrm{H} \cdots \mathrm{Cl}$ hydrogen bonds [the $\mathrm{C}(15) \cdots \mathrm{Cl}(2 \mathrm{C})$ separation is $3.49(4) \AA$, and the $\mathrm{O}(15)-\mathrm{H}(15 \mathrm{~A}) \cdots \mathrm{Cl}(2 \mathrm{C})$ angle is $132.86^{\circ}$, symmetry code $\left.C=x,-y+2, z-1 / 2\right][29,30]$ and $\pi \cdots \pi$ stacking interactions between pyridyl and benzene rings [the centroid-centroid and interplanar separations are $3.58(8)$ and $3.43(8) \AA$, respectively, with the dihedral angle being $\left.7.3^{\circ}\right][32,33]$ (Fig. 4c).
This work provides a point of comparison between two anthracene-based bulky backbone carboxylic acid ligands and their corresponding complexes. The results indicate that the auxiliary ligands play an important role in the formation of frameworks of complexes 1-3, which together with the anthracene-based ligands and different anions may play an important role in both the structures and the luminescent properties of the complexes.

From the above descriptions, we can clearly see that the two anthracene-based ligands 9,10-dioxo-9,10-dihydroanthracene-1,5-dicarboxylic acid $\left(\mathrm{H}_{2} \mathbf{L}^{1}\right)$ and 2-phenylquinoline-4-carboxylic acid $\left(\mathrm{HL}^{2}\right)$ exhibit variable coordination modes. In complex $\mathbf{1}$, the backbone of $\mathrm{H}_{2} \mathbf{L}^{1}$ locates in the same plane, and the dihedral angles between the carboxyl groups and backbone of the ligand are $86.0^{\circ}$ and $92.1^{\circ}$. Therefore, $\mathrm{H}_{2} \mathbf{L}^{1}$ adopts a bis-monodentate bridging mode in $\mathbf{1}$. In complexes $\mathbf{2}$ and $\mathbf{3}$, because of $\mathrm{N} \cdots \mathrm{H}$ small distances [2.442(3)-2.627(1) $\AA$ ], the $\mathrm{N}$ atoms of $\mathrm{HL}^{2}$ cannot 
Fig. 3 View of a the coordination environment of $\mathrm{Mn}^{\mathrm{II}}$ ions in the dinuclear unit of $\mathbf{2}$, $\mathbf{b}$ the 3D supramolecular network showing the intramolecular $\mathrm{O}-\mathrm{H} \cdots \mathrm{O}$, O$\mathrm{H} \cdots \mathrm{N}$ and $\mathrm{C}-\mathrm{H} \cdots \mathrm{O}$ hydrogen bond interactions (partial $\mathrm{H}$ atoms, partial ligand backbones and dissociated aqua molecules omitted for clarity) (a)
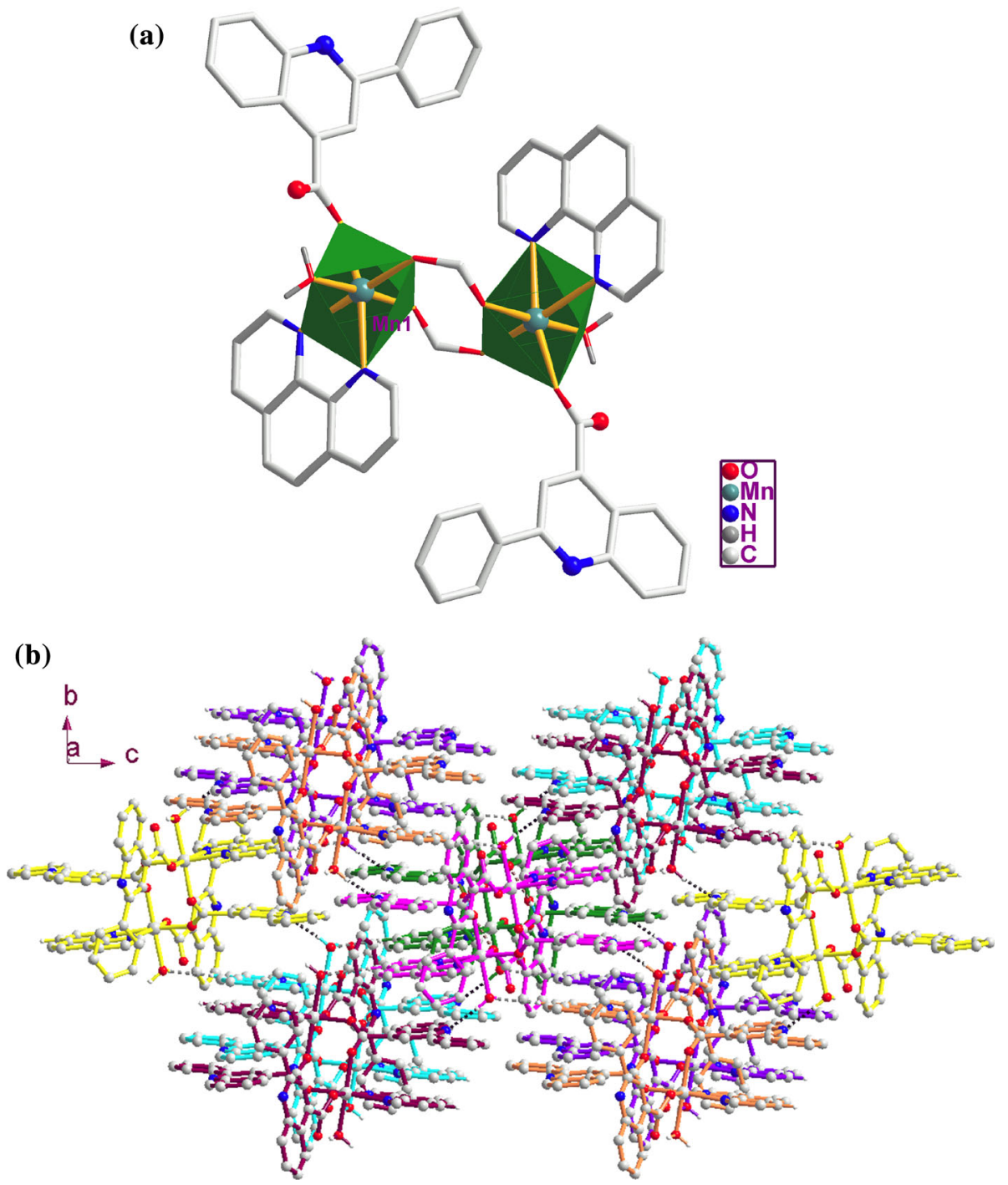

coordinate to the metals. Hence, $\mathbf{L}^{2}$ acts as a monocarboxylate ligand. The dihedral angles between the carboxyl group and ligand backbone are small $\left(23.3^{\circ}, 38.8^{\circ}\right.$ and $36.5^{\circ}$ ). Hence, $\mathrm{HL}^{2}$ adopts rich coordination modes, namely monodentate or bidentate bridging in complex $\mathbf{2}$ and tridentate bridging in complex $\mathbf{3}$.

\section{Spectroscopic properties}

The IR spectra of complexes 1-3 show features attributable to each of their components [34]. A broad band at ca. $3,473-3,374 \mathrm{~cm}^{-1}$ is assigned to the $\mathrm{O}-\mathrm{H}$ stretching of water $[22,34,35]$. The characteristic bands of the carboxylate groups appear in the usual region at $1,573-1,517 \mathrm{~cm}^{-1}$ for the antisymmetric stretching vibrations $\left[v_{\text {as }}\left(\mathrm{COO}^{-}\right)\right]$and at $1,463-1,407 \mathrm{~cm}^{-1}$ for the symmetric stretching vibrations $\left[v_{\mathrm{s}}\left(\mathrm{COO}^{-}\right)\right]$. The $\Delta v$ values $\left[\Delta v=v_{\mathrm{as}}\left(\mathrm{COO}^{-}\right)-v_{\mathrm{s}}\left(\mathrm{COO}^{-}\right)\right]$are 160 and $110 \mathrm{~cm}^{-1}$ for $\mathbf{1}, 146$ and $90 \mathrm{~cm}^{-1}$ for 2,138 and $107 \mathrm{~cm}^{-1}$ for 3 , in good agreement with their solid-state structures from the crystallographic analyses [22, 34, 35].

The solid-state luminescence spectra of complexes 1-3 as well as free ligands $\mathrm{H}_{2} \mathbf{L}^{1}$ and $\mathbf{H L}^{2}$ were investigated at room temperature (see Fig. 5). While $\mathrm{H}_{2} \mathbf{L}^{1}$ and phen display weak luminescence in the solid state at $\lambda_{\max }=432$ and $361 / 379 \mathrm{~nm}$, respectively, upon excitation at $\lambda_{\mathrm{ex}}=380$ and $310 \mathrm{~nm}$, under the same experimental conditions, 1 exhibits intense purple emission at $\lambda_{\max }=432 \mathrm{~nm}$ upon excitation at $380 \mathrm{~nm}$. Upon excitation with $\lambda_{\mathrm{ex}}=380$ and $370 \mathrm{~nm}$, complexes 2 and $\mathbf{3}$ exhibit intense emissions at 390 and $392 \mathrm{~nm}$, respectively, which are close to the emission wavelengths of free $\mathbf{H L}^{2}$, phen and pp (at 388, 361/379 and $410 \mathrm{~nm}$, respectively) [15]. The similarity in the emission wavelengths between complexes 1-3 and the corresponding free ligands suggests that the emission of the complexes can be attributed to 
Fig. 4 View of a the coordination environment of $\mathrm{Cd}^{\mathrm{II}}$ ions in the dinuclear unit of 3, b the 2D supramolecular network showing the intramolecular $\mathrm{C}-\mathrm{H} \cdots \mathrm{Cl}$ hydrogen bond and $\pi \cdots \pi$ stacking interactions (partial $\mathrm{H}$ atoms omitted for clarity) (a)
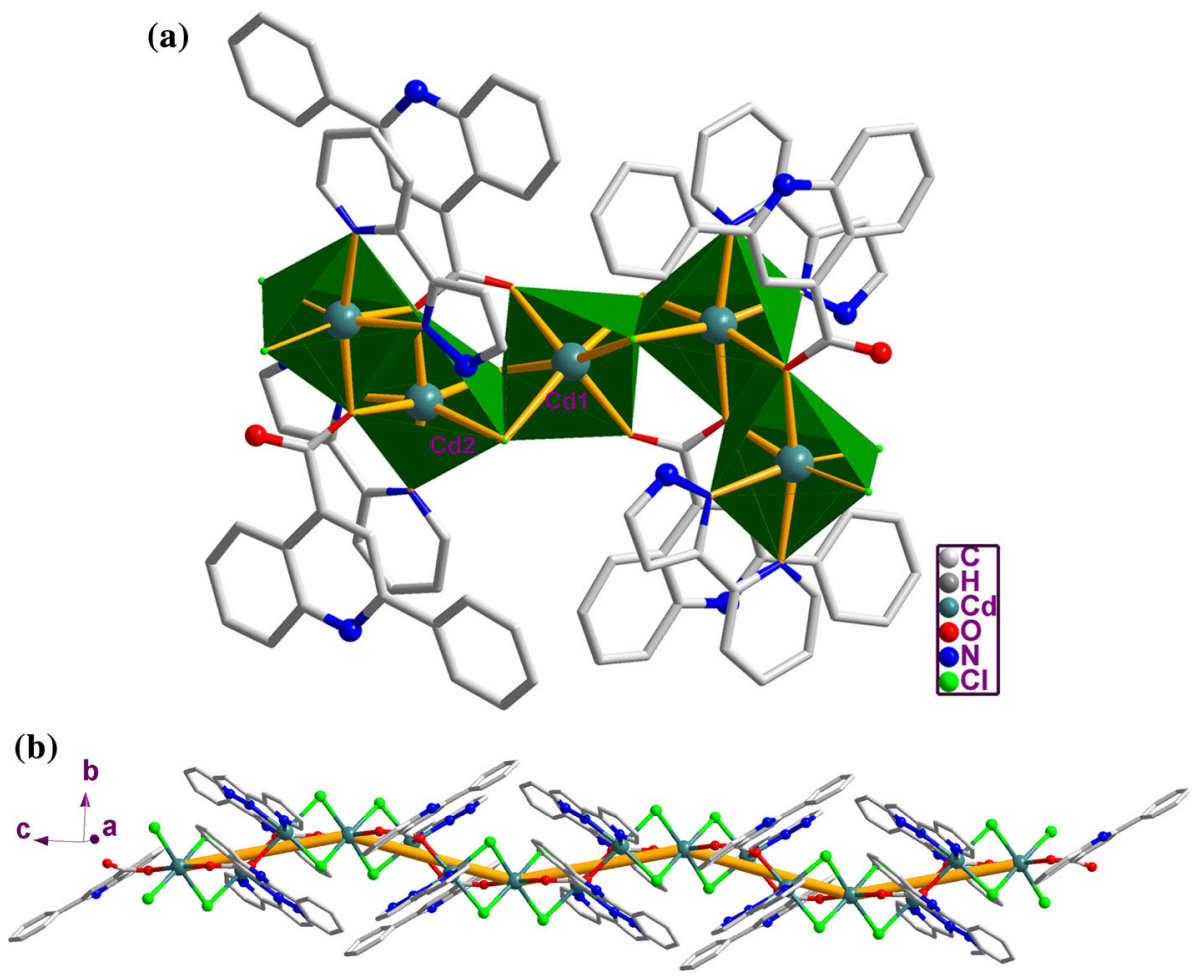

(c)

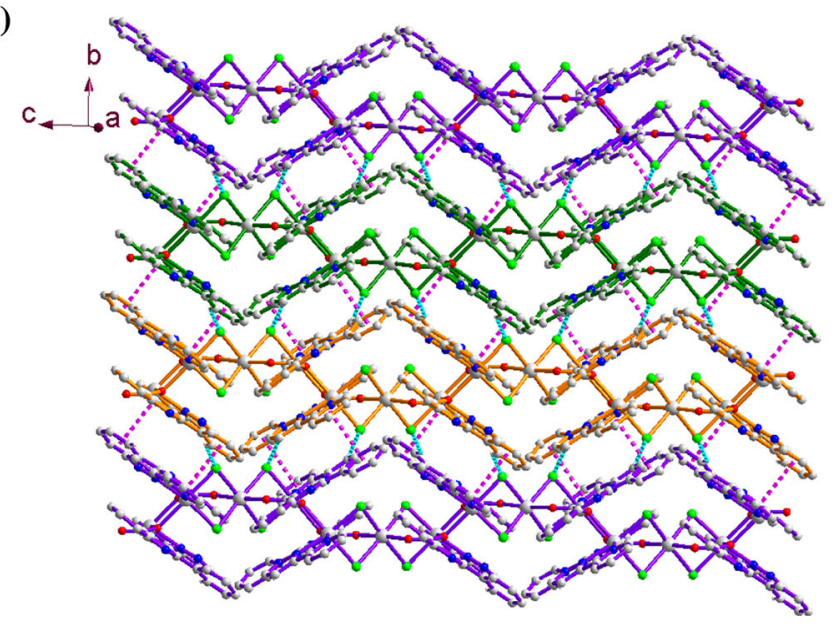

intraligand transfer $\pi^{*}-\pi$ transitions, namely ligand-toligand charge transfer (LLCT), similar to the reported results for other coordination polymers with anthracenebased backbones [36-38]. In addition, the enhanced luminescence intensities of complexes 1-3 compared to the free ligands can be explained by restricted vibration and rotation of the ligands within the complexes, which will decrease the contribution of radiationless deactivation [3638].

Magnetic properties and XRD results

The variable temperature magnetism of complex 2 was tested in the temperature range of $2-300 \mathrm{~K}$ at 2,000 Oe.
The results are shown in Fig. 6 in the form of a plot of $\chi_{\mathrm{m}} T$ versus $T\left(\chi_{\mathrm{m}}\right.$ is the molar magnetic susceptibility for two $\mathrm{Mn}^{\mathrm{II}}$ ions). The value of $\chi_{\mathrm{m}} T$ at $300 \mathrm{~K}$ is $8.13 \mathrm{~cm}^{3}$ $\mathrm{K} \mathrm{mol}^{-1}$, close to the $\chi_{\mathrm{m}} T$ value of two isolated $\mathrm{Mn}^{\mathrm{II}}$ ions with $g=2, S=5 / 2$. The value of $\chi_{\mathrm{m}} T$ decreases along with temperature to $0.71 \mathrm{~cm}^{3} \mathrm{~K} \mathrm{~mol}^{-1}$ at $2 \mathrm{~K}$. This phenomenon shows that an antiferromagnetic coupling interaction exists between the $\mathrm{Mn}^{\mathrm{II}}$ ions in complex $\mathbf{2}$, in accordance with observations for other compounds with carboxyl bridged dinuclear $\mathrm{Mn}^{\mathrm{II}}$ ions $[39,40]$. The CurieWeiss fitting of the data in the temperature range of $10-300 \mathrm{~K}$ for 2 gave values of $C=8.44 \mathrm{~cm}^{3} \mathrm{~K} \mathrm{~mol}^{-1}$ and $\theta=-6.38 \mathrm{~K}$. The negative value of $\theta$ further confirms the existence of antiferromagnetic interactions in 2 [39, 40]. 


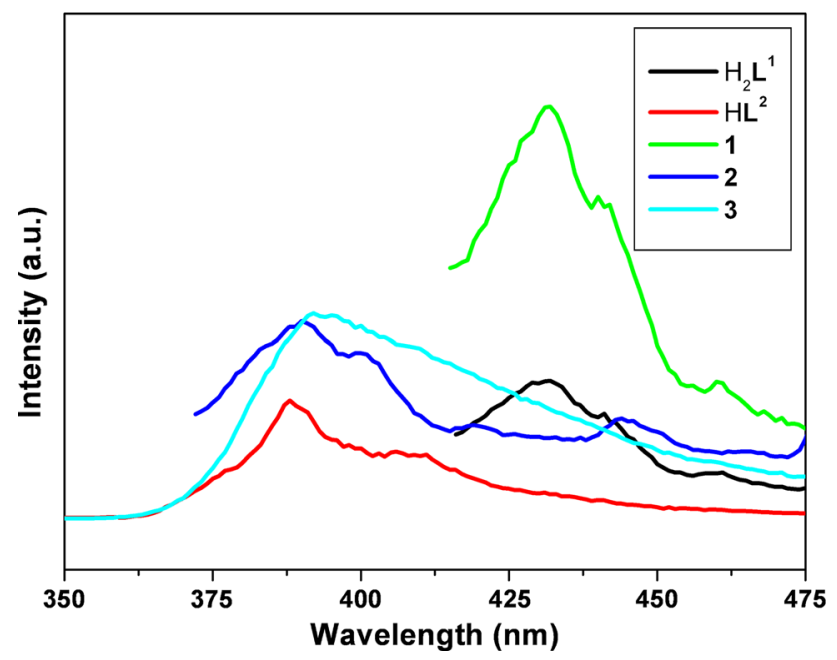

Fig. 5 Solid emission spectra of $\mathrm{H}_{2} \mathbf{L}^{1}, \mathrm{HL}^{2}$ and 1-3 at room temperature $\left(\lambda_{\text {ex }}=380 \mathrm{~nm}\right.$ for $\mathrm{H}_{2} \mathbf{L}^{1}, 279 \mathrm{~nm}$ for $\mathrm{HL}^{2}, 380 \mathrm{~nm}$ for $\mathbf{1}$, $380 \mathrm{~nm}$ for $\mathbf{2}$ and $370 \mathrm{~nm}$ for $\mathbf{3}$, respectively)

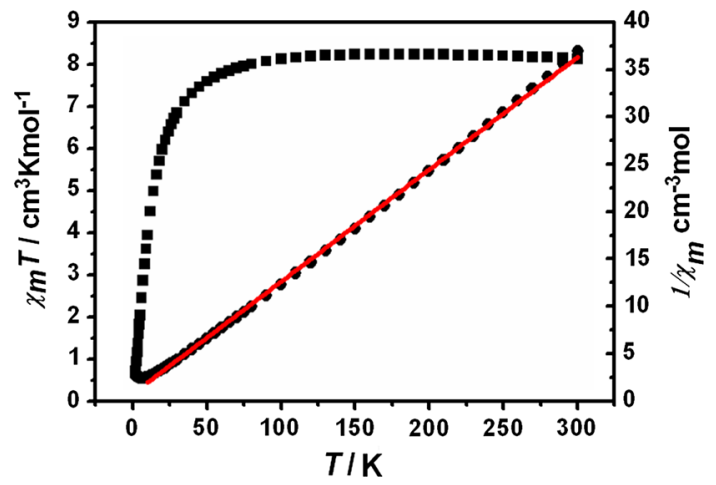

Fig. 6 The plot of $\chi_{\mathrm{M}} T$ (filled square) and $1 / \chi_{\mathrm{M}}$ (filled circle) versus temperature for $\mathbf{2}$

To confirm whether the crystal structures are truly representative of the bulk materials, XRPD experiments have been carried out for complexes 1-3. The experimental and computer-simulated XRPD patterns are shown in Fig. 7. These patterns indicate that the bulk-synthesized materials and as-grown crystals can be considered homogeneous for all three complexes.

\section{Conclusion}

A series of metal-organic coordination compounds of manganese(II) and cadmium(II), generated from two anthracene-based bulky backbone ligands, together with phen or pp as auxiliary ligands, have been prepared. These complexes display diverse structures from binuclear to $1 \mathrm{D}$
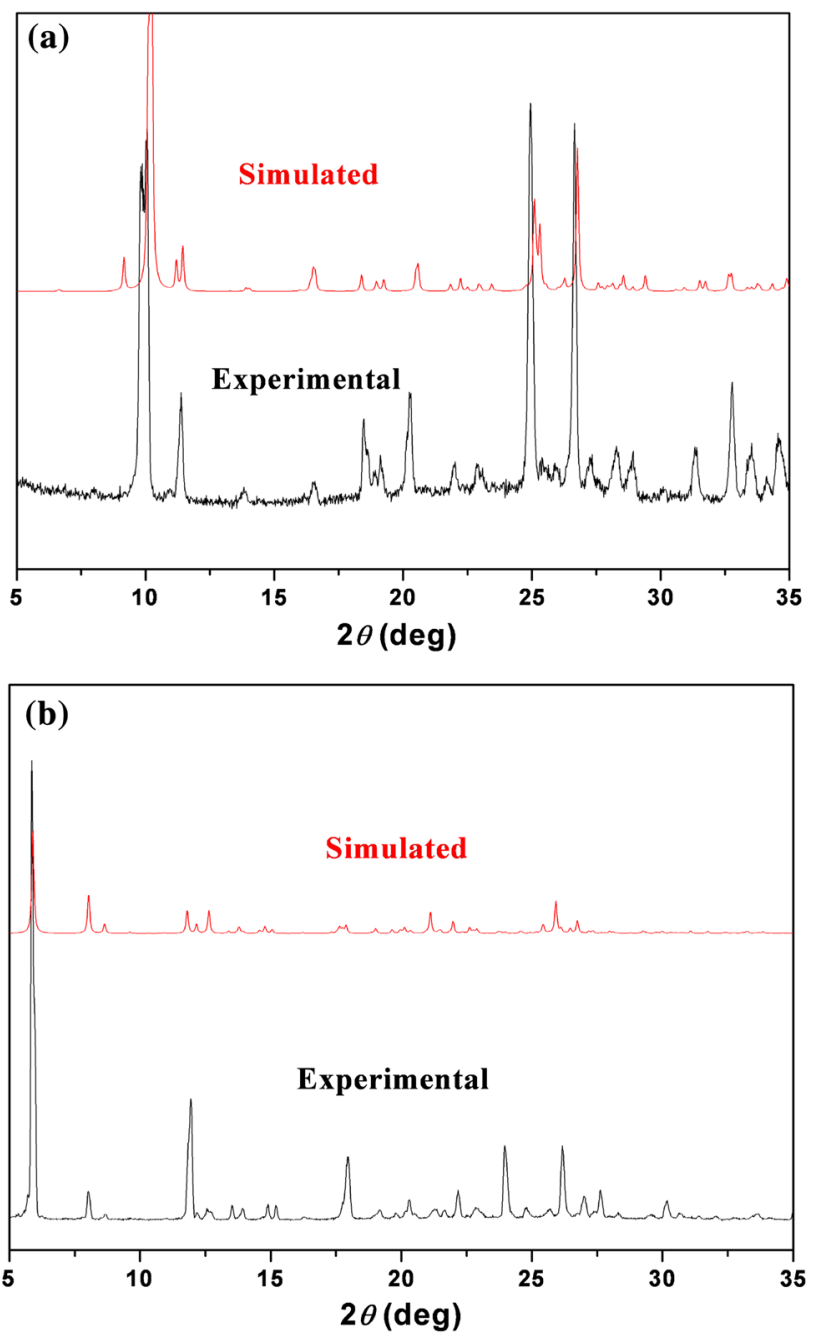

(c)

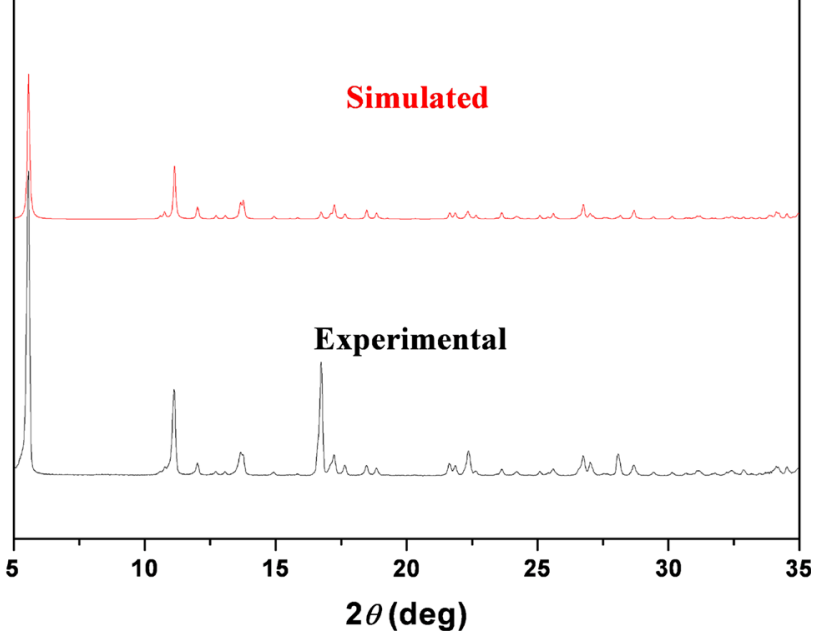

Fig. 7 X-ray powder diffraction (XRPD) patterns of $\mathbf{a}$ for $\mathbf{1}, \mathbf{b}$ for $\mathbf{2}$ and $\mathbf{c}$ for $\mathbf{3}$ 
zigzag chains. This work shows that the reactions of metals with the corresponding ligands are tunable through control of the reaction conditions. The auxiliary chelating ligands phen and pp play an important role in the formation of the frameworks of these complexes, preventing the formation of higher-dimensional structures. Intense luminescent emissions of the complexes were attributed to the LLCT of the corresponding ligands. Antiferromagnetic coupling interactions exist between the binuclear $\mathrm{Mn}^{\mathrm{II}}$ ions in complex 2.

Acknowledgments The work was supported by the Joint Fund for Fostering Talents of National Natural Science Foundation of China and Henan province (No. U1204213), the National Natural Science Foundation of China (Nos. 21403006, 21304001 and 21301009), the Natural Science Foundation of Henan Province (No. 112102210371) and the Science and Technology Research Projects of Education Department of Henan province (12B150003).

Open Access This article is distributed under the terms of the Creative Commons Attribution License which permits any use, distribution, and reproduction in any medium, provided the original author(s) and the source are credited.

\section{References}

1. Sumida K, Rogow DL, Mason JA, McDonald TM, Bloch ED, Herm ZR, Bae TH, Long JR (2012) Chem Rev 112:724. doi:10. $1021 / \mathrm{cr} 2003272$

2. Tian D, Chen Q, Li Y, Zhang YH, Chang Z, Bu XH (2014) Angew Chem Int Ed 53:837. doi:10.1002/anie.201307681

3. Lin ZJ, Lv J, Hong M, Cao R (2014) Chem Soc Rev. doi:10.1039/ C3CS60483G

4. Schneemann A, Bon V, Schwedler I, Senkovska I, Kaskel S, Fischer RA (2014) Chem Soc Rev. doi:10.1039/C4CS00101J

5. Yan Y, Yang S, Blake AJ, Schröder M (2014) Acc Chem Res 47:296. doi:10.1021/ar400049h

6. Phan A, Doonan CJ, Uribe-Romo FJ, Knobler CB, O'Keeffe M, Yaghi OM (2010) Acc Chem Res 43:58. doi:10.1021/ar900116g

7. Liu J, Zhang HB, Tan YX, Wang F, Kang Y, Zhang J (2014) Inorg Chem 53:1500. doi:10.1021/ic402467g

8. Horie M, Suzaki Y, Hashizume D, Abe T, Wu T, Sassa T, Hosokai T, Osakada K (2012) J Am Chem Soc 134:17932. doi:10.1021/ja304406c

9. Liu MM, Hou JJ, Qi ZK, Duan LN, Ji WJ, Han CY, Zhang XM (2014) Inorg Chem 53:4130. doi:10.1021/ic5001232

10. He YP, Tan YX, Zhang J (2013) Inorg Chem 52:12758. doi:10. 1021/ic4020256

11. Fang ZL, Yu RM, Wu XY, Huang JS, Lu CZ (2011) Cryst Growth Des 11:2546. doi:10.1021/cg200300x

12. Hou G, Bi L, Li B, Wu L (2010) Inorg Chem 49:6474. doi:10. 1021/ic1001495

13. Park JH, Lee WR, Kim Y, Lee HJ, Ryu DW, Phang WJ, Hong CS (2014) Cryst Growth Des 14:699. doi:10.1021/cg401583v

14. Bu XH, Tong ML, Chang HC, Kitagawa S, Batten SR (2004) Angew Chem Int Ed 43:192. doi:10.1002/anie.200352024
15. Wang JJ, Liu CS, Hu TL, Chang Z, Li CY, Yan LF, Chen PQ, Bu XH, Wu Q, Zhao LJ, Wang Z, Zhang XZ (2008) CrystEngComm 10:681. doi:10.1039/b710209g

16. Wang JJ, Hu TL, Bu XH (2011) CrystEngComm 13:5152. doi:10. 1039/c1ce05287j

17. Liu Y, He R, Wang F, Lu C, Meng Q (2010) Inorg Chem Commun 13:1375. doi:10.1016/j.inoche.2010.06.046

18. Tong B, Qiang JY, Xu YQ, Mei Q, Duan T, Chen Q, Zhang QF (2011) Inorg Chem Commun 14:1937. doi:10.1016/j.inoche. 2011.08.029

19. Vogt FG, Williams GR, Johnson MN, Copley RCB (2013) Cryst Growth Des 13:5353. doi:10.1021/cg401232g

20. Wang JJ, Chang Z, Zhang AS, Hu TL, Bu XH (2010) Inorg Chim Acta 363:1377. doi:10.1016/j.ica.2010.01.043

21. Feng S, Xu R (2001) Acc Chem Res 34:239. doi:10.1021/ ar0000105

22. Kendall JK, Shechter H (2001) J Org Chem 66:6643 and references therein. doi:10.1021/jo010404p

23. Bruker AXS (1998) SAINT software reference manual. Madison, Wisconsin

24. Sheldrick GM (1996) SADABS, Siemens area detector absorption corrected software. University of Göttingen, Germany

25. Sheldrick GM (1997) SHELXTL NT version 5.1. Program for solution and refinement of crystal structures. University of Göttingen, Germany

26. Wilkinson G, Gillard RD, McCleverty JA (eds) (1987) Comprehensive coordination chemistry, vol 5. Pergamon, Oxford

27. Zheng YQ, Lin JL, Chen BY (2003) J Mol Struct 646:151. doi:10.1016/S0022-2860(02)00615-4

28. Zhang Y, Li J, Zhu M, Wang Q, Wu X (1998) Chem Lett 1051. doi:10.1246/cl.1998.1051

29. Desiraju GR, Steiner T (1999) The hydrogen bond in structural chemistry and biology. Oxford University Press, Oxford

30. Alekseyeva ES, Batsanov AS, Boyd LA, Fox MA, Hibbert TG, Howard JAK, MacBride JAH, Mackinnon A, Wade K (2003) Dalton Trans 475. doi:10.1039/B209931D

31. Li WW, Bing Y, Zha MQ, Li TH, Li X (2011) Acta Crystallogr Sect E 67:m1464. doi:10.1107/S1600536811039341

32. Janiak C (2000) J Chem Soc Dalton Trans 3885 and references therein. doi:10.1039/B003010O

33. Khlobystov AN, Blake AJ, Champness NR, Lemenovskki DA, Majouga AG, Zyk NV, Schröder M (2001) Coord Chem Rev 222:155. doi:10.1016/S0010-8545(01)00370-8

34. Nakamoto K (1986) Infrared and Raman spectra of inorganic and donor hydrogen bond coordination compounds. Wiley, New York

35. Deacon GB, Phillips RJ (1980) Coord Chem Rev 33:227. doi:10. 1016/S0010-8545(00)80455-5

36. Balasubramanian K (1997) Relativistic effects in chemistry part A: theory and techniques; part B: applications. Wiley, New York

37. Valeur B (2002) Molecular fluorescence: principles and applications. Wiley-VCH, Weinheim

38. Miyasaka H (2013) Acc Chem Res 46:248. doi:10.1021/ ar300102t

39. Li X, Cai Y, Fang Z, Wu L, Wei B, Lin S (2011) Cryst Growth Des 11:4517. doi:10.1021/cg200730k

40. Chang XH, LF LF, Hui G, Wang LY (2012) Cryst Growth Des 12:3638. doi: $10.1021 / \operatorname{cg} 300461 \mathrm{v}$ 